Tel.: + 41 (0) $31 / 3230943$

Fax: + 41 (0) $31 / 3233659$

E-Mail: danielle.buetschi@swr.admin.ch

Internet: http://www.ta-swiss.ch

$\gg$

\section{From participative TA to TA as "participant" in the social shaping of technology}

\author{
by Annegrethe Hansen and Christian Clau- \\ sen, Technical University of Denmark
}

Though the Danish technology assessment activities were initiated from an "early warning" perspective meant to foresee and meet critiques and unintended consequences, the TA initiatives took a number of different directions from the beginning of the 1980s. These directions were shaped both by the institutional background of the activities, and by the existing organisational traditions, as well as by the participating actors.

The initiated activities have had strong participative and constructive elements with the involvement of a multitude of different groups and players such as politicians, journalists, scientists, technology developers and lay people. Political debates following the publication of first the "red" and later the "green" technology assessment report, led to technology assessments characterised by a comprehensive approach and with a prevalence for environmental, working life, health and socioeconomic consequences.

In the following different projects and approaches will be described, as well as the role of participative and constructive elements in these projects. The role of the technology assessment studies in the shaping of new technology at the company and the broader societal levels will be discussed. It will be put forward that the contribution of technology assessments to the shaping of technology has been dependent on the type of debate they can raise and the contribution to a broader cultural movement that involves awareness and skills among engineers and companies as well as among users and citizens.

\section{Development of TA in Denmark}

The Danish technology assessment arena responded early to the technology assessment promoting activities of the OECD and the experiences and institutional developments in the US. The Danish activities were however to a large degree transformed into proactive, dialogue and participation oriented TA approaches. Both US and Danish strategies emphasized policy makers' interest in an early warning of new technologies and their potential consequences as input for policy-making. The ambition of these considerations was, on the basis of technological foresight, to promote technology development and to regulate potential negative impacts, as two sides of advancing technological development and growth.

The Danish as well as the international initiatives with regard to setting technology assessment on the agenda was the concerned reaction to a number of technological, environmental and energy developments in the 1970s. The concerns regarded the negative consequences of new technology for marginalisation, employment, the environment and occupational health and safety, and the possibility for workers and the public to influence this development. The criticism was raised amongst other by the trade unions, environmental organisations and by critical students and researchers at universities with regard to the consequences of technological development. The proactive role of trade unions seems to be largely a European phenomena, though occupational health and safety was also an issue in the US.

In 1980 the "red" report of the Technology Council of the Ministry of Industry on how technology assessment might be undertaken (Teknologirådet 1980), raised debate on the report's suggested "partial" orientation. This debate and the performance of some pilot technology assessments, led to the "green" report, also published by the Technology Council (Teknologirådet 1984), which emphasized comprehensive technology assessment and proactiveness, prominent features in the majority of later technology assessments.

A first institutionalisation of explicit TA activities came at the beginning of the 1980s. The Danish Ministry of Industry launched a 
number of technology development programmes on information technology (IT), telecommunication, biotechnology and new materials, in which technology assessment activities were included. These TA activities have perhaps been the most prominent activities within a number of different types of technology assessment activities, including production and process technology assessment activities at company and industry levels as well as national policy oriented technology assessment activities.

A special experimental participatory activity was established as the result of a parliamentary decision on investments in a Danish broad band data transmission net. The aim of the parliamentary decision was to ensure that people in the near periphery would be able to benefit from the net and would have equal opportunities. This was attempted by providing education of users as well as user participation (Cronberg 1992).

Technology assessment activities were also included in the Social Science Research Council's Technology-Society Initiative from 1983 to 1990 . Embedding the initiative within the scientific community had implications for the TA activities of, for example, trade unions and policy institutions. Despite the scientific affiliation, the activities are referred to by Cronberg (1992) and Munch (1995) an others as being constructive and action oriented.

As part of the strong technology promoting policies of the 1980s TA was funded as a parallel activity to research and development programmes. In the large Biotechnology Programme of the Ministry for Research and Development in 1987, technology assessment was included, but as an activity separated from the biotechnology R\&D. However, the later inclusion in a natural science $R \& D$ programme in which there was no interest in the social aspects and consequences of scientific development, led to the exclusion of TA activities in later government programmes.

In the late 1990s, the Danish Board of Technology - the Danish parliamentary TA unit - stands out as the central representative of participative technology assessment. Since 1987 the Board has had a role as both initiator of technology assessment projects and as developer and organiser of consensus confer- ences. Especially with regard to the new biotechnology, the Board has supported the TA activities of non-governmental organisations (NGOs). The former as well as the current Board of Technology has a function of informing the Danish Parliament and raising public debate, and as such had resources for TA activities based on gathering existing knowledge. From 1995 the Board has had fewer resources and has to a larger extent been coordinator of activities rather than initiating them.

In the following, three examples of Danish technology assessment activities from the past 20 years will be presented. The different participative characteristics, or the absence of these, will be outlined, and the role of participation discussed. The role of social shaping of technology development and the role of TA in this process, are touched upon in the summary statements.

\section{Partipative TA in Technology and Working Life}

The context of technology and working life is heavily institutionalised with established distributions of actor roles for developing competitiveness and work. Consequently, the choice of strategy for participative TA is highly coloured by residuals of former policy and change concepts. In this context a range of strategies have been tried out emphasising different types of collaboration between company management, workers, engineers, suppliers and trade unions.

Each strategy in itself seems to have specific strong and weak points concerning its effect on the social shaping of technology. A cooperative strategy may seem suited to engage the management in a development project. It may even be possible to establish a cooperative situation involving local trade union people. But it is very likely that those concerned with (a critical examination of) technology and work are excluded from the discussions. A critical dimension may be promoted by giving the views of trade unions or workers a stronger voice through a collective resource approach. The company management will probably accept such a project, although reluctantly, but then again the aspect of the social shaping of technology is often excluded because the tech- 
nical departments or suppliers are not involved. As a consequence, TA researchers may engage themselves with technical experts and develop alternative technical artifacts. But then trade union people will very likely loose in importance and furthermore, the technology in question will not be implemented by the management (Clausen 1998).

One paradigmatic approach of the 1980s was oriented towards the development of new methods for the design of products and work processes. This orientation resembled the later "Constructive Technology Assessment" tradition even though the term TA was not used. These projects also aimed at changing the trade unions' attitude towards technology and hence union technology policy, creating a movement from a very defensive to at more offensive strategy implying the demand for an alternative technology. Projects concerned with the development of an alternative technology were launched in close collaboration between trade unions, skilled workers, sociologists and computer scientists.

A broader perspective in the projects was to demonstrate the socially constructed character of technology. Craft oriented, practical or "tacit" knowledge was seen as an important basis for the shaping of technology according to the needs and demands of the individual worker or a group of workers. This category of projects includes the "Utopia-project" in which graphical workers (printers), computer experts and sociologists developed a software system for graphical text and image processing. These studies became pilot studies, trying to break the deterministic technology concept of the potential actors.

The potential of this alternative technology approach was as follows: It was expected to enable the integration of technology assessment into the research and development phases which, in principle, have a considerable scope for alternatives. The longer term effects of these approaches or strategies of alternative technology was to motivate actors in central positions within the technological development system, engineers etc., to use new design methods and incorporate user demands on work environments and users views and qualifications. Such target groups in principle possess the position, the power and the resources for incorporating the know-how and methods from technology assessment studies into the technological development activities. Using new design methods may over time change the technology developers' conception of the needs and situation of the users, and thereby of the development process itself.

The immediate effect of the alternative technology approach has in practice been limited to adapting technology to practical uses in new areas in which, for example, data processing has hitherto been only weakly disseminated: small enterprises, specialized administrative tasks, systems for decision support etc. This also indicates that the dominant trend towards more tayloristically shaped technological development and the dominant working environment problems were not influenced (Clausen 1998).

In all it seems likely that participative TA projects in relation to the development and use of production technology and information technology (IT) were midwives not only for specific technology developments, but also for the diffusion and creation of new markets for IT. Changing design practices along with participative approaches can be seen not just as a result of a single project, but as a longer term impact on design practices among computer scientists and engineers and as partly integrated in management strategies for the implementation of technology.

Opposing tendencies, can however also be observed. In recent participative projects it has been shown that new management strategies, such as Business Process Re-engineering and the development and introduction of Enterprise Resource Planning Systems, seldom involve workers and trade unions except for information gathering and implementation.

\section{Social experiments and learning in ICT}

An important part of the Danish TA dialogue and participative experiences were gained in the 1980s as part of a Danish programme for social experiments with the use of information and communication technology (ICT) related to the development of a new telecommunication infrastructure (Cronberg 1992). From 1986 to 198916 experiments were implemented, covering a wide range of information and tele- 
communication technology applications. Some of these applications were located in telecommunication centres in which local citizens were invited to test whether telecommunication devices, video communication and computers were of any interest to them. Guidance was made available as well as courses in word processing and book-keeping for small enterprises.

As part of the experiments, also more advanced applications were initiated by potential users of video-communication. In one case, a group of farmers developed the idea of establishing a video-link for transmission of pictures from the farmers' stables and fields to the veterinarian or the plant counsellor. This application was meant to fill the gap between a telephone call and a visit on the spot and was expected to be of use in disease diagnosis and prevention. As it turned out such an idea led to the identification of a range of shortcomings in the technology and spurred innovation in the development department of a telecommunication company (Cronberg 1992).

A range of examples indicate how the social experiments contributed to the appropriation and social shaping of ICT. First, for potential users they provided an opportunity for learning about the technology and its organisation. Second, development departments and suppliers learned a lot about users and utilization patterns and (to some extent) how to comply with non professional user needs and expectations. Third, suppliers and users constructed new services and markets.

But, on the other hand it seems that these experiments did not affect the major trajectory of technological development, as the experiments were rather isolated from the centres of technological design and development. The experiments did not seriously question the ICT industry's and government's technology push rationale of the broadband network. Furthermore, later Danish governmental IT policies of the 1990s (the IT 2000 programme) did not adopt the approaches and lessons learned of the 1980 s, as an unquestioned strong technology push approach was chosen.

More important, there is evidence that the experiments of the 1980s have left traces of changed practices in certain development environments and IT consultancies working for the public sector. Here, user participation and experimentation seem to have become tools for innovation and development as an integrated element of design practices (Jæger 2000). This implies, according to Jæger, that a long term result of the experimental TA projects is that no one talks about social experiments with ICT. Instead an experimental culture has developed in public sector administrations, where politicians and civil servants no longer talk about social experiments, they just do it and talk about development projects or just "activities".

\section{Comprehensive societal TA and consum- ers' distaste for GMOs}

The "early warning" inspired technology assessment activities in Denmark mostly had regulatory and political actors as addressees, both TA with an emphasis on identifying driving forces and barriers for technological development, as well as TA focusing on unintended and unwanted consequences. Especially some of the IT and telecommunication TA projects analysed driving forces and barriers for technology development (Skouby, Falch, and Henten 1995), while the new biotechnology assessment projects encompassed broader environmental and socio-economic impacts (Kvistgaard et al. 1983), as well as consumer participation (Jelsøe 1990).

The IT and telecommunication technology assessment projects were inspired to some extent by the American technology assessment activities in their taking the technology for granted. But the projects' focus on market conditions and on the projection of potential markets included both, very optimistic technological potentials as well as the socio-economic conditions, and thus the effect of these conditions on the developed technology.

The proactive and macro-oriented character of the assessments meant that anticipated demand and the "missing" subject were regarded as "participants" in the TA process, as were the anticipated "victims" of the developments. But the inevitable technology development, the developers, the users and the victims were "constructed", i.e. determined by the assumptions of the research groups. The TA projects in the IT field became important in a 
certain period because they demonstrated the macro-economic costs of the introduction of the technology, and the (uneven) distribution of the potential benefits. Though there was very little direct participation or participative ambition, the "silent subjects" were given a voice and thus became "participants" in the discussions of the further development of IT and telecommunication.

Some of the TA projects on the new biotechnology also took the technology for granted, but the affected parties were regarded as being closer to the actual technology development, including innovators as well as critics. The proactive and action oriented approach in the TAs on biotechnology was to a large extent, but not explicitly, directed towards policy making and regulation. Policy and regulation were regarded as capable of promoting (certain) technology developments as well as regulating and compensating their negative consequences. This attitude was inspired by thinking in terms of the economics of innovation, but in the TA projects this resulted in a greater participative element with consideration of the interests of those affected as well as of the potentially affected. The projects together with later analyses of national developments of genetically modified organisms (GMO) (Hansen 2000) have demonstrated how certain technologies and their use were influenced by the participants in the process, but also how the changing technology activated new groups of participants, including international actors. The projects however also showed how difficult it is to change the fundamental technology development agenda of large and often multinational companies.

The projects with their focus on more or less specific interests and their inherent constructive approach are similar to other projects claiming "institutionalisation" of especially the environmental criticism (Jamison 1999). But developments since 1996 regarding genetically engineered plants and foods, have made explicit the difficulties in institutionally legitimising developments to the more diffuse "consumers" or "the public" who in opinion polls and consumer tests reject genetically engineered foods.

Other biotechnology TA projects had a more direct involvement of users. The projects which focused on the use of new biotechnology for foods, involved users as well as food industry workers more directly in the formulation of demands on foods and the use of genetic engineering within food production. The projects' aim was to gain a better (more detailed) understanding of the consumers' scepticism towards genetically modified foods, and an understanding of how participation in a food production agenda could be established.

As far as the development of the new biotechnology is concerned, the failure of legitimising certain technological developments and the ensuing public debate, have led to other forms of participatory TA activities in an effort to smooth or steer technological development. In some companies, ministries, research and development institutions, and in some extraparliamentary fora, different parties have been brought together in consensus conferences, dialog fora, focus groups etc. to discuss those uses of the new biotechnology which might be beneficial for society and ethically acceptable. Fora often mean more technology specific participation, but they might also mean less opportunity for asking more fundamental or radical questions on, for example, the use of genetic engineering.

Thus, although the participative elements were not very distinct in the TA activities mentioned, the projects themselves might have acted as important contributions in setting certain agendas and in representing users, consumers and the public, either by actually giving them a voice in the TA projects or by "casting" them as users or victims.

\section{From participation to social shaping}

As demonstrated above, participation as a meeting between diverse perspectives on technology to a large extent can be regarded as characterising Danish technology assessment activities. The Danish TA activities have experimented with a range of methods which implied a direct or indirect representation of a variety of actors. The participatory and constructive emphasis in many of the TA activities is a distinct characteristic of Danish TA activities, as is also acknowledged by others. The TA activities and the methods developed to a large degree responded to various "participants", 
such as NGOs, trade unions, local communities, consumers etc. who were involved in public debate and in technological and societal development.

Despite the absence of a participative agenda or method in some of the technology assessment projects, these assessments in a number of cases contributed to the involvement of users or participants, either by making users and participants aware of certain developments and thus leading to action, or by making, for example, politicians and companies aware of the "silent users" or non-users. The projects thus established themselves as an actor, not only in relation to policymakers, but also in relation to a broader arena of technology development.

Although technology assessment activities as explicitly designed activities have almost disappeared in Denmark, with the exception of the Danish Board of Technology and medical technology assessments, TA elements and experiences are found in a number of new approaches, in academia as well as in company and policy strategies.

Examples of the use of technology analyses, impact and risk assessments and assessment methods can be found in action oriented working life research, socio-technical system design, and in environmental management as well as in top-down oriented change programmes related to, for example, quality management, and environmental management (as mentioned counter developments can also be observed). Also similarity in the methods used can be identified, for example, in analyses by university researchers, sector institutions, public administration, private consultants and among grass roots organisations.

Many of these analyses and assessments, especially in the universities, belong to the broad field of the social shaping of technology. Whereas the current technology assessment activities in Denmark have a tendency to exclude technological as well as social developments from the core of the analyses, the social shaping approach attempts to overcome this limitation. The acceptance of changing technological and societal agendas, changing structural and political conditions and different and varying perspectives of participants and the inclusion of these changes as dynamic elements in the analyses, are indicators that a better understanding of the "socio-technological" development is aimed at.

Therefore, although the TA activities as individual participatory approaches have demonstrated limitations for a broader understanding of the socio-technological context, we claim that they played and continue to play an important role for the dynamics in the social shaping of technology. Furthermore we state that TA, instead of being regarded as a series of single events, will be an important part of both more academic as well as practical analyses of the social shaping of technology development, governmental regulation, and institutional development.

\section{References}

Bellucci et al., 1998: Participatory Technology Assessment . Its Features, Functions, Limitations and Impacts in Modern Developed Societies. A theoretical framework. July 1998, Workshop paper. Copenhagen: Danish Board of Technology.

Clausen, Ch., 1998: Action Research Strategies Concerned with Technology and Working Life. In: Christiansen, Hansen and Møller (red.): Eds.), Arbejdet under forandring, forandring af arbejdet. Tema Nord 1998:550. København: Nordisk Ministerråd, pp. 179-194.

Clausen, Ch., Lorentzen, B. and Rasmussen, L.B. (red.), 1992: Deltagelse i teknologisk udvikling. København: Fremad.

Cronberg, T. and Friis, D. (red.), 1990: Metoder i teknologivurdering. København: Blytman.

Cronberg, T., 1992: Technology Assessment in the Danish Socio-Political Context,. TVI Texts No. 9. Lyngby: DTU.

Hansen, A., 2000: Danish development of genetically engineered herbicide resistant beets and the role of environmental controversies. Danish country account of the growing of genetically modified plants and their use. Report for the EU project "Consumer, environmental and sectoral networks in the societal management of food technology". Unpublished. report. Department of Technology and Social Sciences. Lyngby: DTU.

Jager, B., 2000: Some Lessons of Social Experiments with Technology. Paper presented at the EASST 2000 conference in Vienna, September 2000.

Jager, B.; Manniche, J. and Rieper, O, 1990: Computere, lokalsamfund og virksomheder. Evaluering af Egvad Teknologifors $\emptyset \mathrm{g}$ og Erhvervsprojektet i Ringkøbing Amt. København: AKF Forlaget. 
Jamieson, A.(Ed.), 1998: Technology Policy Meets the Public. PESTO Papers 2. Aalborg: Aalborg University Press.

Jelsøe, E., 1990: Bioteknologi i levnedsmiddelsektoren. Konsekvenser for ansatte og forbrugere. København: Teknologinævnet.

Kvistgård, M. et al., 1983: Gensplejsning, bioteknologi og samfundsudvikling. Beskrivelse, teori og metode. Udfordring for Danmark i 1980'erne. Lyngby: DTH.

Munch, B., 1995: Danish Approaches in Social Studies of Technology. Tekster om Teknologivurdering nr. 14, Teknologivurderingsinitiativet. Lyngby: DTU.

Remmen, A., 1991: Clean Technologies in the Fish Processing Industry, A Constructive Technology Assessment. Workshop, University of Twente, The Netherlands.

Skouby, K.E.; Falch, M. and Henten, A, 1995: Social and economic impact of telecommunications. Centre for Tele-Information. Lyngby: DTU.

Teknologirådet / The Danish Board of Technology, 1980: Teknologivurdering i Danmark. København: Teknologirådet.

Teknologirådet / The Danish Board of Technology, 1984: Organisering af teknologivurdering i Danmark - erfaringer og perspektiver. København.

\section{Contact}

\section{Christian Clausen}

Department of Technology and Social Sciences

Technical University of Denmark

Building 307, Matemetiktorvet

DK-2800 Lyngby

Tel.: + 454525 6069; Fax: + 4545882014

E-mail: cc@its.dtu.dk

http://www.its.dtu.dk

\section{$\gg$}

\section{A Precautionary Approach to Technology Appraisal? - A multi-criteria mapping of genetic modification in UK agriculture}

\author{
by Andrew Stirling, University of Sussex, \\ and Sue Mayer, GeneWatch UK
}

The prospect of genetically modified crops and foods has become a political hot potato in Britain. Food industry executives, government advisors and biotechnologists have been caught unaware of the strength and persistence of public concern. The pilot study by SPRU on multi-criteria mapping of genetically modified crop in agricultural systems in the UK shows how in such an overheated political arena highly polarized disputants can participate constructively in discussion and regulatory appraisal and create a "map" of the debate surrounding GM crops.

\section{Some Key Difficulties in Technology Appraisal}

The social appraisal of technological risk has always been a difficult undertaking. With diminishing public confidence in traditional expert institutions and procedures, the difficulties seem to be growing. In some quarters, there has been a tendency to see this as mere cultural fashion - reflecting the ephemeral anxieties of the "risk society" (Giddens 1991; Beck 1992; Lash et al. 1996). Under this view, the answer lies in basing the regulatory appraisal process on "sound science", keeping it as free as possible from the messy and emotive business of politics. In this regard, aspiring "scientific" techniques, such as probabilistic risk assessment and cost-benefit analysis, are sometimes held to offer rational, robust and objective aids to "science based" decision-making.

Unfortunately, the difficulties in the social appraisal of technological risk are not so easily resolved. Although the language of "sound science" remains prominent, the available methods and procedures manifestly fail to deliver on the rhetoric. This is not simply a matter of practice failing to live up to potential. Ironically, the reasons for the failure of "sound sci- 